Research Article

\title{
Protagonist Action of Plant Growth Regulators and Sublethal-Tem- perature in Inducing Thermotolerance in Green Gram (Vigna radiata) Seedlings
}

\author{
Simeen Mansoor, Jabeen Farheen* and Meher Hassan
}

Department of Genetics, KU Circular Road, Faculty of Science, University of Karachi, Main University Road, Karachi-75270, Pakistan.

Abstract | The specific proteins induced by sublethal-temperature are molecular chaperons that positively regulate plant growth and development that govern acclimation in plants but little has been known under lethal-temperature stress. Thus, the impact of induction of thermotolerance by sublethal-temperature (40 $\left.{ }^{\circ} \mathrm{C}\right), 100 \mu \mathrm{M}$ indoleacetic acid (IAA), and $100 \mu \mathrm{M}$ gibberellic acid (GA3) before lethal-temperature stress $\left(50{ }^{\circ} \mathrm{C}\right)$ were assessed on green gram growth and protein profile. For this purpose, the distilled-water and phytohormones imbibed seeds of NM13-1 were pretreated with $40{ }^{\circ} \mathrm{C}$ ( 1 hour) before $50{ }^{\circ} \mathrm{C}(2$ hours), after 24 hours seedling length, proteome profile by 1-D, and catalase (CAT), ascorbate (APX), and guaiacol peroxidase (GPX) activities were assessed. Study outcomes revealed that the combination of phytohormones and $40^{\circ} \mathrm{C}$ before $50{ }^{\circ} \mathrm{C}$ exhibited improved growth and increased activity of APX, CAT, and GPX as to control and lethal-temperature treatments. The total soluble protein profile showed highly significant variations and was broadly divided into two major clusters. The 116, 113, 109, 106, 94, 86, 76, 62, and $61 \mathrm{kDa}$ fractions were identified the first time, which may be involved in temperature stress acclimation. Conclusively, the sublethal-temperature along with phytohormones are involved in green gram growth, proteome expression, and thermotolerance via initiating antioxidant defense signaling.

Received | November 28, 2020; Accepted | March 07, 2021; Published | May 15, 2021

*Correspondence | Jabeen Farheen, Department of Genetics, KU Circular Road, Faculty of Science, University of Karachi, Main University Road, Karachi-75270, Pakistan; Email: farheenj.uok@gmail.com

Citation | Mansoor, S., Farheen, J. and Hassan, M., 2021. Protagonist action of plant growth regulators and sublethal-temperature in inducing thermotolerance in green gram (Vigna radiata) seedlings. Journal of Innovative Sciences, 7(1): 103-110.

DOI | https://dx.doi.org/10.17582/journal.jis/2021/7.1.103.110

Keywords | Cluster analysis, Gibberellic acid, Heat stress, Indoleacetic acid, Mungbean, Thermotolerance

\section{Introduction}

G reen gram is one of the most popular legumes in Asian countries including Pakistan, whose growth is negatively affected by lethal-temperature stress. Plants have a different optimum temperature for their best growth performance similarly green gram performs very well under $30{ }^{\circ} \mathrm{C}$ (Farheen et al., 2018). Furthermore, a temperature higher than optimum could lead to limited crop production and lethality. The lethal-temperature stress causes alterations in the expression of genes involved in direct protection from heat stress (Siddiqui et al., 2017; Khan et al., 2020). Furthermore, different plant species synthesize stress proteins to protect plants from the adverse effect of lethal-temperature stress (Siddiqui et al., 2017). Lethal-temperature may change membrane fluidity and osmotic effect (D'souza and Devaraj, 2013). Irreversible changes under lethaltemperature stress in cellular homeostasis may occur due to inadequate response during signaling and gene activation processes, responsible for the destruction 
of structural activity ultimately leading to cell death (Siddiqui et al., 2017; Wang et al., 2018; Khan et al., 2020). Another reason for cell death is the excessive production of reactive oxygen species (ROS) which is the outcome of lethal-temperature stress, interacts with many cellular components (Khan et al., 2020).

The exposure of plants with moderately hightemperature before lethal-temperature causes thermotolerance (D'souza and Devaraj, 2013). Plants showing delayed heat-acclimation responses may be more sensitive to thermo-damage (D'souza and Devaraj, 2013). Other than exposure to moderately high-temperature, application of phytohormones is another effective way of inducing thermotolerance in plants, as these have growth-promoting and effective antioxidant capacity (D'souza and Devaraj, 2013). There is a number of antioxidant enzymes like catalase, guaiacol peroxidase, and ascorbate peroxidase which scavenge the increased levels of ROS (Khan et al., 2020). Exogenous application of phytohormones like indoleacetic acid and gibberellic acid is an effective method in mitigating heat stress-induced damage in plants and has growth-promoting and antioxidant capacity (Siddiqui et al., 2017; Farheen and Mansoor, 2020). The main objective of this study was to evaluate the damaging effect of heat stress on the growth, antioxidant enzymes, and protein profile of green gram. Also, the experiment was performed to find out the pretreatment effect of $40{ }^{\circ} \mathrm{C}$ and phytohormones on the acquisition of thermotolerance.

\section{Materials and Methods}

\subsection{Plant material and experimental treatments}

The seeds of green gram genotype NM 13-1 were obtained from the National Agricultural Research Center (NARC), Islamabad, Pakistan, and imbibed separately in distilled water (DW), $100 \mu \mathrm{M}$ IAA and $100 \mu \mathrm{M} \mathrm{GA} 3$ for 20 hours (h). Afterward, green gram 20 seeds treatment ${ }^{-1}$ replication ${ }^{-1}$ were allowed to germinate for $24 \mathrm{~h}$ at $30^{\circ} \mathrm{C}$ (optimum temperature) in Petri dishes lined with two layers of filter paper moistened with DW. The two days old seedlings were divided into three groups. The first group labeled as control was kept at $30{ }^{\circ} \mathrm{C}$ for $3 \mathrm{~h}$ while the second group received sub-lethal temperature treatment as $40^{\circ} \mathrm{C}$ for $1 \mathrm{~h}$ then subjected to $50^{\circ} \mathrm{C}$ heatshock for $2 \mathrm{~h}$. The last group placed for $1 \mathrm{~h}$ under optimum temperature $\left(30{ }^{\circ} \mathrm{C}\right)$ of green gram then exposed to lethal heat stress treatment $\left(50{ }^{\circ} \mathrm{C}\right)$ for
$2 \mathrm{~h}$. Subsequently, seedlings were allowed to grow at $30^{\circ} \mathrm{C}$ for a further $24 \mathrm{~h}$ then harvested and saved for morphological and biochemical analysis.

\subsection{Growth, biomolecules, and protein profiling}

The total length of green gram seedling was recorded (Farheen et al., 2018). The extraction of antioxidant enzymes was performed by the method of Mansoor and Naqvi (2013). Protein was estimated by the method of Lowry et al. (1951). GPX, APX, and CAT activity were measured by monitoring the decrease in absorbance due to hydrogen peroxide $\left(\mathrm{H}_{2} \mathrm{O}_{2}\right)$ by the method of Mansoor and Naqvi (2013). SDS-PAGE was performed as previously described the method of Farheen and Mansoor (2020). Cluster analysis and genetic similarity indices were calculated by statistical software SPSS version 20 and dendrogram was constructed using presence or absence of protein bands in the treatments.

\subsection{Statistical analysis}

The experiment was conducted at the lab of the Department of Genetics, the University of Karachi in complete randomized design (CRD) with three replications (Steel and Torrie, 1997) and ANOVA was performed by statistical software SPSS version 20. Means were compared by using Duncan's multiple range test (DMRT) at $\mathrm{P} \leq 0.05$ level of significance.

\section{Results and Discussion}

\subsection{Growth and biomolecules}

Plant growth is the most vital factor which irreversible increase size through cell division to form different parts of the plant (D'souza and Devaraj, 2013). It is essential to understand the complex mechanism of plant growth under lethal-temperature stress for the selection of competent genotypes of species. In this context, the protagonist action of various treatments such as sublethal-temperature along with two plant growth regulators was studied on green gram seedlings growth and biomolecules under lethal-temperature stress (Table 1). It was observed that the seedling length was significantly reduced to $61 \%$ at lethal-temperature stress $\left(50{ }^{\circ} \mathrm{C}\right)$ that was improved $30 \%$ by the imbibition of $100 \mu \mathrm{M}$ IAA before pretreatment of $40{ }^{\circ} \mathrm{C}$ for $1 \mathrm{~h}$ to $50{ }^{\circ} \mathrm{C}$. Also, the pretreatment of IAA $+50{ }^{\circ} \mathrm{C}$ and $\mathrm{GA} 3+50{ }^{\circ} \mathrm{C}$ helped green gram seedlings to recover from lethaltemperature stress (Figure 1). Similar findings were reported earlier from lablab beans, where exposure 
to extreme temperature produced ROS in excessive amount which ultimately harmed seedling length and fresh weight of seedlings (D'souza and Devaraj, 2013). Furthermore, an enhancement in the length of green gram seedling may have been due to the production of stress acclimation proteomes and the active synthesis of antioxidant enzymes. Moreover, an accumulation of heat-shock proteins and enzymes either in active or passive form is an imperative defense mechanism for thermotolerance in various plant species to defend cell organelles from severe injury due to dehydration (Wang et al., 2018; Khan et al., 2020).

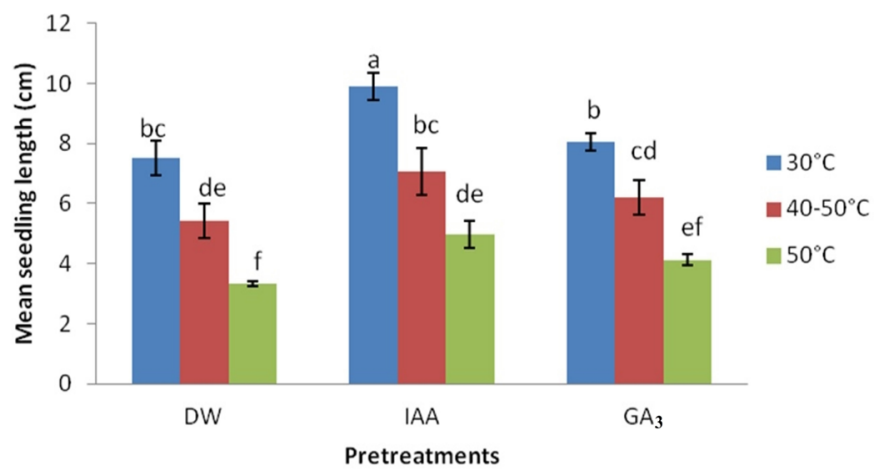

Figure 1: Effect of distilled water as control (DW for $20 \mathrm{~h}$ ), gibberellic acid (GA3 for $20 \mathrm{~h}$ ) and indoleacetic acid (IAA $20 \mathrm{~h}$ ) imbibition, and prestress treatment of sub-lethal temperature $\left(40^{\circ} \mathrm{C}\right.$ for $1 \mathrm{~h})$ on seedlings length of green gram under lethaltemperature stress. Vertical bars indicate standard error $(n=3)$, and significant differences $(P \leq 0.05)$ are marked with different letters.

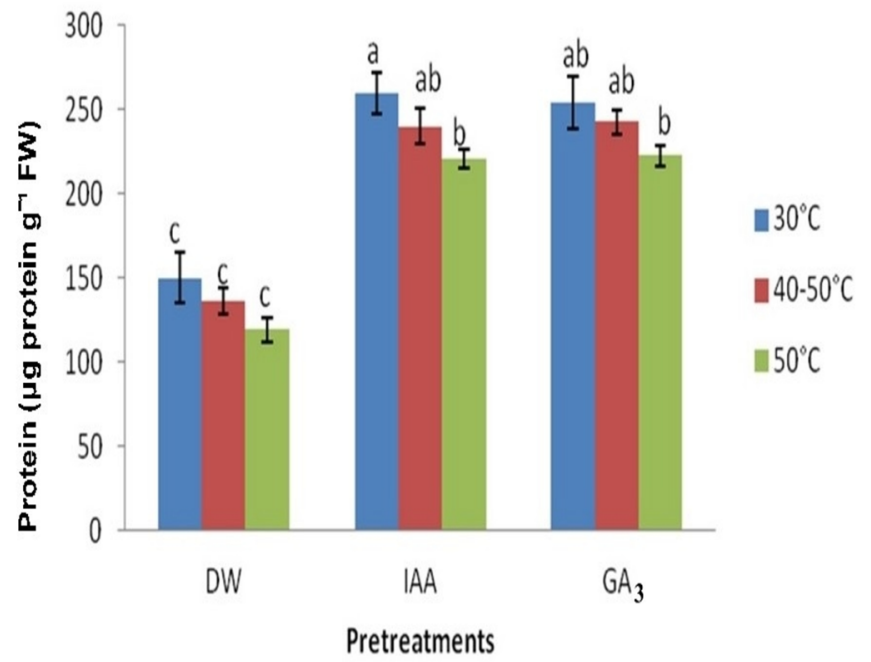

Figure 2: Effect of DW, GA3, IAA and $40^{\circ} \mathrm{C}$ on the total soluble protein of green gram under lethaltemperature stress. Vertical bars indicate standard error $(n=3)$, and significant differences $(P \leq 0.05)$ are marked with different letters.

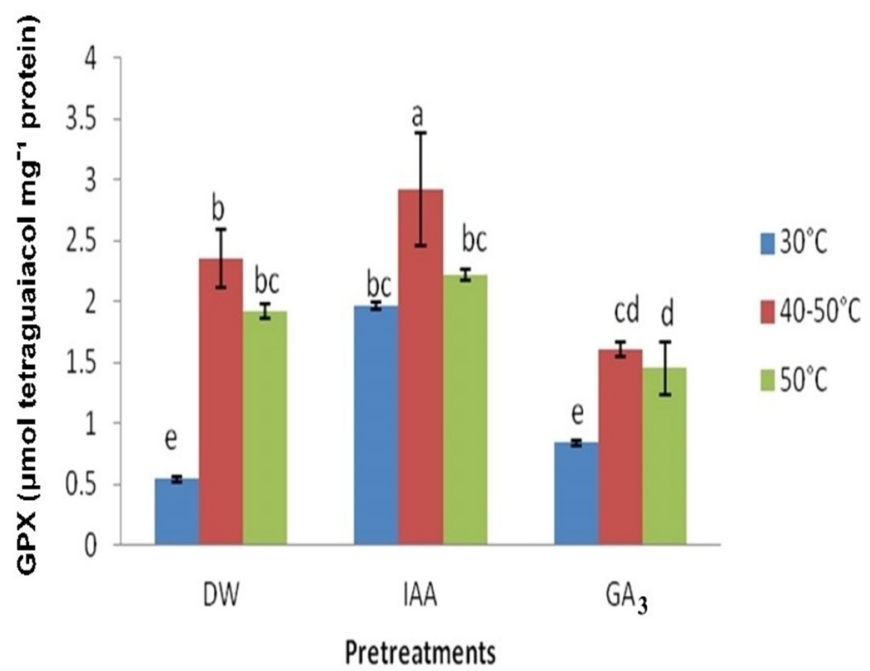

Figure 3: Effect of DW, GA3, IAA, and $40^{\circ} \mathrm{C}$ on ascorbate peroxidase (APX) activity in green gram under lethal-temperature stress. Vertical bars indicate standard error $(n=3)$, and significant differences $\left(P_{\leq} \mathbf{0 . 0 5}\right)$ are marked with different letters.

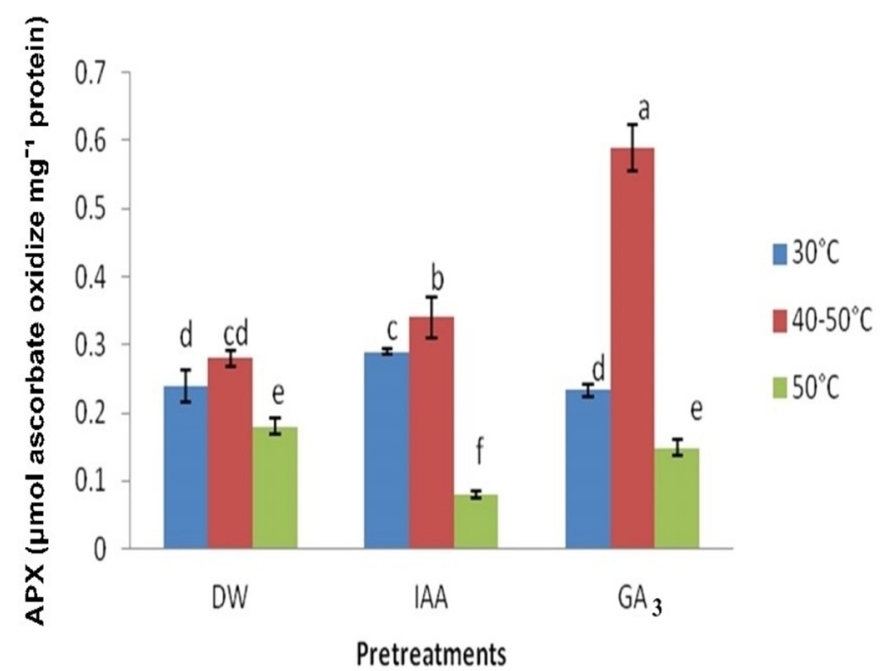

Figure 4: Effect of DW, GA3, IAA and $40^{\circ} \mathrm{C}$ on catalase (CAT) activity in green gram under lethaltemperature stress. Vertical bars indicate standard error $(n=3)$, and significant differences $(P \leq 0.05)$ are marked with different letters.

Under lethal-temperature stress, proteins, and antioxidants defense enzymes biosynthesis are alleviated in response to ROS (D'souza and Devaraj, 2013). The ROS mainly hydrogen peroxide and superoxide ion caused oxidative destruction in the plant cells as a result cell death occur. To rescue plant, cells scavenge superoxide ions through the production of GPX and SOD metalloprotein, and hydrogen peroxide degradation is accomplished via CAT and APX enzymes (Farheen et al., 2018). To 
recognize whether thermotolerance in green gram is related to the generation of proteins and antioxidant enzymes, $24 \mathrm{~h}$ phytohormones imbibed seedlings were analyzed for biomolecules level at lethal-temperature stress. In seedlings, both phytohormones together with $40{ }^{\circ} \mathrm{C}$ help to enhance $65 \%$ total soluble protein during lethal-temperature treatment in comparison to control $\left(30{ }^{\circ} \mathrm{C}\right.$ ) (Figure 2). Treatment of green gram seedling that is, IAA $+40{ }^{\circ} \mathrm{C}+50{ }^{\circ} \mathrm{C}$ resulted in outmost i.e. 500\% GPX activity indicating that treatment-induced antioxidant enzyme synthesis most efficiently than other treatments (Figure 3). While APX and CAT were found to be $200 \%$ and $100 \%$ higher in $\mathrm{GA} 3+40{ }^{\circ} \mathrm{C}+50{ }^{\circ} \mathrm{C}$ treatment, respectively (Figures 4-5). Therefore, the overproduction of antioxidants may responsible for further oxidative protection against $\mathrm{H}_{2} \mathrm{O}_{2}$. These observations are in consonance with GPX activity detected in hightemperature stress-tolerant lablab bean (D'souza and Devaraj, 2013). Likewise, numerous scientists have reported that elevated CAT and APX activities are related to the capability of species to recover from lethal-temperature stress when tolerant by using phytohormone and sublethal-temperature treatment (Siddiqui et al 2017; Khan et al., 2020). Also, APX and CAT are the most effective enzymes to prevent cellular damage by the detoxification of hydrogen peroxide into water molecules (Farheen et al., 2018). Additionally, the decrease in CAT and APX activity under lethal-temperature was due to the denaturation of proteins and antioxidant enzymes (Awasthi et al., 2015; Wang et al., 2018). Thus, an induction in antioxidant enzyme activity can be considered as an important mechanism to scavenge ROS and protect the cell from stress.

\subsection{Protein profile}

The response of lethal-temperature stress to green gram seedlings is also explained by the altered synthesis of proteins. It was observed that the different plant species show thermotolerance by synthesizing a group of proteins called stress proteins (Wang et al., 2018). In this context, the protein profile of green gram seedlings after different treatments was analyzed which revealed significant variations among control and treated samples (Table 2). The dendrogram was constructed among treatments based on the presence and absence of protein bands (Figure 6). The total of nine temperature treatments was broadly divided into two major clusters according to the percent homology. The largest cluster-I was composed of I-A and I-B. The sub-cluster I-A was minor, contained $\mathrm{GA} 340-50{ }^{\circ} \mathrm{C}$ and $\mathrm{GA} 350{ }^{\circ} \mathrm{C}$ which showed $99 \%$ similarity. While, sub-cluster I-B was the major one, consisted of four treatments in which, IAA $30{ }^{\circ} \mathrm{C}$ and $\mathrm{GA} 330{ }^{\circ} \mathrm{C}$ were $93 \%$ similar. Further, the IAA 40-50 ${ }^{\circ} \mathrm{C}$, and IAA $50{ }^{\circ} \mathrm{C}$ exhibited $92 \%$ and $88 \%$ similarity, respectively with IAA $30{ }^{\circ} \mathrm{C}$ and GAs 30 ${ }^{\circ} \mathrm{C}$ treatments. The cluster I-A was $84 \%$ similar to the cluster I-B. The cluster-II was also divided into II-A and II-B. Cluster II-A has two treatments namely 30 ${ }^{\circ} \mathrm{C}$ and $40-50{ }^{\circ} \mathrm{C}$ that were $93 \%$ similar to each other. Whereas, the sub-cluster II-B $\left(50{ }^{\circ} \mathrm{C}\right.$ treatment) was $89 \%$ like sub-cluster II-A.

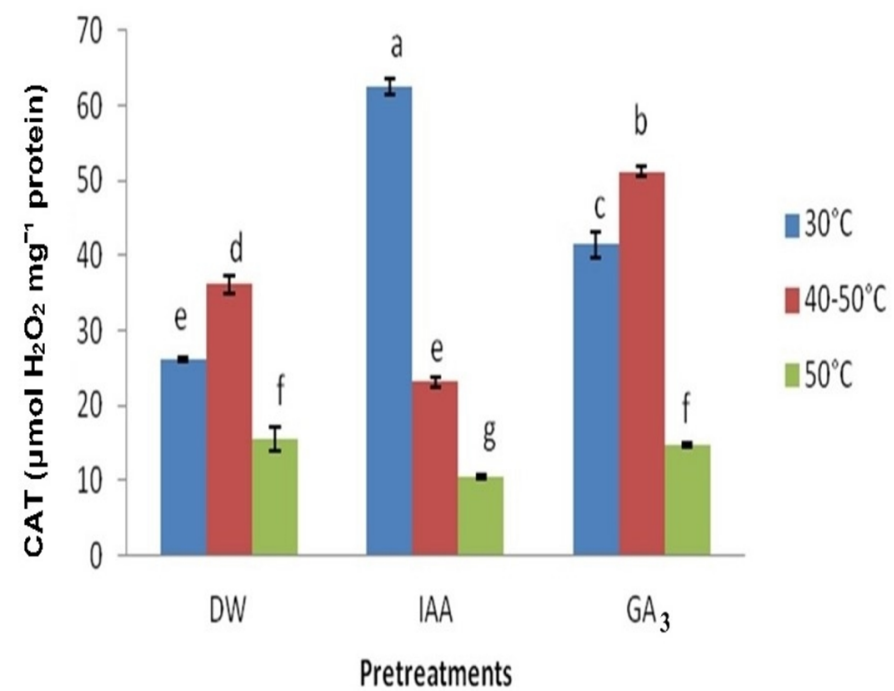

Figure 5: Effect of DW, GA3, IAA, and $40^{\circ} \mathrm{C}$ on guaiacol peroxidase (GPX) activity in green gram under lethal-temperature stress. Vertical bars indicate standard error $(n=3)$, and significant differences $\left(P_{\leq} 0.05\right)$ are marked with different letters.

Table 1: Mean squares of seedling length, total soluble protein, GPX, APX, CAT between different treatments on NM13-1 genotype of green gram.

\begin{tabular}{lllllll}
\hline Sources of variations & \multirow{2}{*}{ Df } & \multicolumn{5}{c}{ MS } \\
\cline { 3 - 7 } & & Length & Protein & GPX & APX & CAT \\
\hline B/w treatment & 8 & $12.81^{*}$ & $8892.7^{* *}$ & $1.953^{*}$ & $0.006^{*}$ & $953.19^{* *}$ \\
Within treatment & 18 & 0.717 & 316.815 & 0.111 & 0.001 & 3.379 \\
CV\% & & 33.4 & 26.5 & 43.4 & 55.6 & 54.9 \\
\hline
\end{tabular}

${ }^{*}$ as significant difference at $\mathrm{P} \leq 0.05$ and ${ }^{* *}$ as significant difference at $\mathrm{P} \leq 0.01$ level of significance. 
OPEN 2 ACcess

Mansoor et al.

Table 2: Presence (+) and absence (-) of protein molecular weight (MW) bands based on relative mobility (RF) in green gram seedlings treated with two phytohormones and sublethal-temperature to acquire thermotolerance.

\begin{tabular}{|c|c|c|c|c|c|c|c|c|c|c|c|}
\hline Bands & RF & MW (kDa) & 30 & $40-50$ & 50 & IAA30 & IAA 40-50 & IAA50 & GA330 & GA3 40-50 & GA350 \\
\hline 1 & 0.17 & 116 & - & - & - & + & + & + & + & + & + \\
\hline 2 & 0.19 & 113 & - & + & + & - & - & - & - & + & + \\
\hline 3 & 0.20 & 109 & - & - & - & + & + & + & + & - & - \\
\hline 4 & 0.22 & 106 & + & - & + & - & - & - & + & - & + \\
\hline 5 & 0.23 & 103 & - & + & + & + & + & + & - & + & + \\
\hline 6 & 0.25 & 100 & - & - & - & + & - & + & + & - & + \\
\hline 7 & 0.28 & 94 & - & - & - & - & - & - & - & + & - \\
\hline 8 & 0.29 & 91 & + & + & - & + & + & - & + & - & + \\
\hline 9 & 0.30 & 86 & - & - & + & - & - & + & - & + & + \\
\hline 10 & 0.32 & 80 & - & - & - & + & + & - & + & + & - \\
\hline 11 & 0.33 & 76 & + & + & + & - & - & - & - & - & - \\
\hline 12 & 0.35 & 71 & - & - & - & + & + & - & + & + & + \\
\hline 13 & 0.36 & 67 & + & + & + & - & - & + & - & - & - \\
\hline 14 & 0.38 & 62 & + & - & - & - & + & + & + & - & - \\
\hline 15 & 0.39 & 61 & - & - & + & + & - & - & - & + & - \\
\hline 16 & 0.41 & 60 & + & + & - & - & - & - & - & - & - \\
\hline 17 & 0.42 & 59 & - & - & - & - & - & - & - & + & - \\
\hline 18 & 0.43 & 58 & - & - & - & - & - & - & - & + & - \\
\hline 19 & 0.45 & 57 & + & + & + & + & - & - & - & - & - \\
\hline 20 & 0.46 & 56 & - & - & - & - & + & + & + & - & - \\
\hline 22 & 0.49 & 55 & + & + & + & + & - & - & - & - & - \\
\hline 23 & 0.51 & 54 & - & - & - & + & + & + & + & - & - \\
\hline 24 & 0.52 & 53 & + & + & + & - & - & - & - & - & - \\
\hline 25 & 0.54 & 52 & - & - & - & - & + & - & - & + & - \\
\hline 27 & 0.57 & 51 & + & + & + & + & - & + & + & - & - \\
\hline 28 & 0.59 & 49 & - & - & - & - & - & + & + & + & + \\
\hline 29 & 0.61 & 48 & - & + & - & - & - & - & - & - & - \\
\hline 30 & 0.64 & 47 & - & - & + & - & + & - & - & - & - \\
\hline 31 & 0.65 & 46 & + & - & - & + & - & + & + & + & + \\
\hline 32 & 0.67 & 43 & - & + & + & - & - & - & - & + & + \\
\hline 33 & 0.68 & 41 & - & - & - & - & + & - & - & - & - \\
\hline 34 & 0.70 & 39 & - & - & - & - & - & + & - & - & - \\
\hline 35 & 0.71 & 37 & - & + & + & + & - & - & + & - & - \\
\hline 36 & 0.72 & 35 & - & + & - & - & + & + & + & + & + \\
\hline 37 & 0.74 & 33 & + & - & + & + & - & - & - & - & - \\
\hline 38 & 0.75 & 31 & - & + & - & - & - & - & - & - & - \\
\hline 39 & 0.77 & 29 & - & - & - & - & - & - & + & - & - \\
\hline 40 & 0.78 & 28 & - & - & - & - & - & + & - & - & - \\
\hline 41 & 0.80 & 27 & + & - & - & + & + & - & + & + & + \\
\hline 42 & 0.81 & 24 & - & - & + & - & - & - & - & - & - \\
\hline 43 & 0.83 & 22 & + & + & - & + & + & + & - & - & - \\
\hline 44 & 0.84 & 20 & - & - & - & - & - & - & + & - & - \\
\hline 45 & 0.86 & 18 & - & - & - & - & - & - & - & + & + \\
\hline 46 & 0.87 & 16 & - & - & + & + & + & + & + & + & + \\
\hline \multirow[t]{2}{*}{47} & 0.88 & 15 & - & + & - & - & - & - & - & - & - \\
\hline & Total & & 14 & 17 & 17 & 18 & 16 & 17 & 19 & 18 & 15 \\
\hline
\end{tabular}




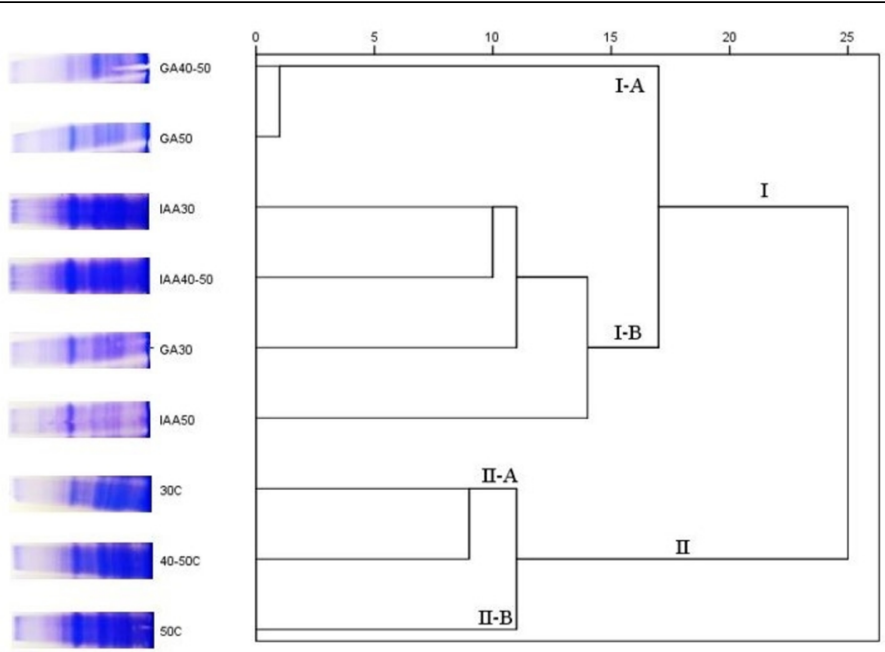

Figure 6: Dendrogram demonstrates the relationship between nine temperature and two phytohormone treatments on green gram seedlings, tested on the base of the protein profile.

The protein profiling revealed 116, 113, 109, 106, 94, 86, 76, 62 and $61 \mathrm{kDa}$ fractions were unknown proteins that have first time identified in the current study. Other than these, 103, 100, 91, 80, $71,67,60,59,58,57,56,55,54,53,52,51,49,48$, $47,46,43,41,39,37,35,33,31,29,28,27,24,22$, $20,18,16$, and $15 \mathrm{kDa}$ were also found during the present investigation. Where $100 \mathrm{kDa}$ proteome was coactivator-like protein (Sato et al., 1998), 91 $\mathrm{kDa}$ act as sucrose synthase SS1 protein (Hameed et al., 2012), $80 \mathrm{kDa}$ was an outer envelope protein in Arabidopsis thaliana (Tabata et al., 2000), $58 \mathrm{kDa}$ was trans-cinnamate 4-monooxygenase (Mizutani et al., 1993), $51 \mathrm{kDa}, 35 \mathrm{kDa}$ and $24 \mathrm{kDa}$ were seed maturation proteins of Glycine max genome (Hameed et al., 2012; Farheen and Mansoor, 2020), and $49 \mathrm{kDa}$ was putative $\mathrm{NADH}$-ubiquinone oxidoreductase subunit (Hameed et al., 2012; Gostincar et al., 2019; Farheen and Mansoor, 2020). While $47 \mathrm{kDa}$ was chloroplastic photosystem II protein (Dempewolf et al., 2010), $46 \mathrm{kDa}$ was PP2A phosphatase-associated protein (Farheen and Mansoor, 2020), $39 \mathrm{kDa}$ was NADH-ubiquinone oxidoreductase (Brumm et al., 2015), $33 \mathrm{kDa}$ was heat-shock protein 33 (Hamidian et al., 2015; Farheen and Mansoor, 2020), $31 \mathrm{kDa}$ was U11/U12 small nuclear ribonucleoprotein (Salanoubat et al., 2000), $27 \mathrm{kDa}$ was alpha-coixin or soybean toxin protein (Vasconcelos et al., 2008) and $18 \mathrm{kDa}$ was peptidyl-prolyl cis-trans isomerase (Kaga and Ishimoto, 1998).

Miclaus et al.(2011) identified that the $22 \mathrm{kDa}$ protein related to the prolamin alpha zein $\mathrm{z} 1 \mathrm{C} 1 \_8$ precursor and Guo et al. (2013) found that the $15 \mathrm{kDa}$ has belonged to the prolamin beta zein precursor. Further, the $71,67,56$, and $53 \mathrm{kDa}$ peptide is vicilin $7 \mathrm{~S}$ subunit and $60 \mathrm{kDa}$ was $8 \mathrm{~S}$ vicilin subunit that was reported earlier in the mung bean genotypes (Hameed et al., 2012). While $52 \mathrm{kDa}$ was $8 \mathrm{~S}$ globulin alpha subunit (Ding et al., 2008) and $16 \mathrm{kDa}$ was $7 \mathrm{~S}$ globulins (Mendoza et al., 2001). Also, the serine/threonineprotein phosphatase associated $2 \mathrm{~A}$ regulatory subunits B' were found in three isoforms like 59 $\mathrm{kDa}$ gamma isoform, $57 \mathrm{kDa}$ kappa isoform, and 55 $\mathrm{kDa}$ beta isoform. Some other proteome including chloroplastic proteins such as $48 \mathrm{kDa}$ dolichyldiphosphooligosaccharide glycosyltransferase subunit, $41 \mathrm{kDa}$ stem-loop binding protein, $37 \mathrm{kDa}$ FKBP12interacting proteins, $29 \mathrm{kDa}$ thylakoid luminal protein, and signal recognition particles having 54 and $43 \mathrm{kDa}$ molecular weight were reported earlier in $M$. pruriens (Nnadi et al., 2018). Hameed et al. (2012) and Nnadi et al. (2018) were also found heatand acid-stable phosphoprotein and chaperonin associated with 28 and $20 \mathrm{kDa}$ molecular weights bands, respectively. Moreover, the variations in band number and intensity were also found in green gram genotypes under salt stress (Farheen and Mansoor, 2020). Hence, protein profiling of green gram revealed that the phytohormones such as IAA and GA3 could regulate the expression of heat shock proteins that are anticipated to play a vital part in the mechanism of heat tolerance.

\section{Conclusions and Recommendations}

The results presented in this study revealed that the imbibition of green gram seeds in plant growth regulator and treatment of sub-lethal temperature $\left(40{ }^{\circ} \mathrm{C}\right)$ before lethal-temperature stress $\left(50{ }^{\circ} \mathrm{C}\right)$ were easy and effective methods to induce thermotolerance at seedlings stage. This conclusion was drawn on the basis of improved growth, enhance the activity of antioxidant enzymes and significant variations in protein profile. Thus, it can be stated that lethaltemperature stress adversely affected the green gram physiology and biochemistry that was improved by the pretreatment of sublethal-temperature and phytohormones.

\section{Acknowledgments}

The research has been funded by the Dean Science Research Grant (University of Karachi). The 
authors are thankful to the National Agricultural Research Center (Islamabad) for providing green gram germplasm. Also, the authors are grateful to acknowledge Scherago International, New Jersey, to present some part of this work in the 'Plant and Animal Genome XXIV International Conference', San Diego 2016.

\section{Novelty Statement}

Protein profiling via SDS-PAGE is the pivotal method in terms of discovering novel proteomes under various phytohormones together with sublethal-temperature treatment before lethal temperature. In this context, the study has found $116,113,109,106,94,86,76,62$, and $61 \mathrm{kDa}$ proteome fractions for the first time in mungbean.

\section{Author's Contribution}

Simeen Mansoor has conceptualized the study, conduct the experiment, analysis the outcomes and initially draft the findings. Jabeen Farheen drafted whole research findings and done protein profiling by using Excel-2016 and SPSS v.20 software. Meher Hassan critically reviewed the study.

\section{Conflict of interest}

The authors have declared no conflict of interest.

\section{References}

Awasthi, R., Bhandari, K. and Nayyar, H., 2015. Temperature stress and Redox homeostasis in agricultural crops. Front. Environ. Sci., 3: Article ID 11. https://doi.org/10.3389/ fenvs.2015.00011

Brumm, P., Monsma, S., Keough, B., Jasinovica, S., Ferguson, E., Schoenfeld, T., Lodes, M. and Mead, D.A., 2015. Complete genome sequence of Thermus aquaticus Y51MC23. PLoS One, 10(10): Article ID e0138674. https://dx.doi. org/10.1371\%2Fjournal.pone.0138674

D'souza, M.R. and Devaraj, V.R., 2013. Induction of thermotolerance through heat acclimation in lablab bean (Dolichos lablab). Afr. J. Biotech., 12: 5695-5704. https://doi.org/10.5897/ AJB2013.13074

Dempewolf, H., Kane, N.C., Ostevik, K.L., Geleta, M., Barker, M.S., Lai, Z., Stewart, M.L., Bekele, E., Engels, J.M.M., Cronk, Q.C.B. and
Rieseberg, L.H., 2010. Establishing genomic tools and resources for Guizotia abyssinica (L.f.) Cass. the development of a library of expressed sequence tags, microsatellite loci, and the sequencing of its chloroplast genome. Mol. Ecol. Resour., 10(6): 1048-1058. https://doi. org/10.1111/j.1755-0998.2010.02859.x

Ding, L.W., Sun, Q.Y., Wang, Z.Y., Sun, Y.B. and $\mathrm{Xu}$, Z.F., 2008. Using silica particles to isolate total RNA from plant tissues recalcitrant to extraction in guanidine thiocyanate. Anal. Biochem., 374(2): 426-428. http://doi. org/10.1016/j.ab.2007.11.030

Farheen, J. and Mansoor, S., 2020. Anti-stress phytohormones impact on proteome profile of green gram (Vigna radiata L.) under salt toxicity. World J. Biol. Biotechnol., 5(2): 17-21.

Farheen, J., Mansoor, S. and Abideen, Z., 2018. Exogenously applied salicylic acid improved growth, photosynthetic pigments and oxidative stability in mungbean seedlings (Vigna radiata) at salt stress. Pak. J. Bot., 50(3): 901-912.

Gostincar, C., Turk, M., Zajc, J. and GundeCimerman, N., 2019. Fifty Aureobasidium pullulans genomes reveal a recombining polyextremotolerant generalist. Environ. Microbiol., 21(10): 3638-3652. https://dx.doi. org/10.1111\%2F1462-2920.14693

Guo, X., Yuan, L., Chen, H., Sato, S.J., Clemente, T.E. and Holding, D.R., 2013. Non redundant function of zeins and their correct stoichiometric ratio drive protein body formation in maize endosperm. Plant Physiol., 162(3): 1359-1369. https://dx.doi.org/10.1104\%2Fpp.113.218941

Hameed, A., Qureshi, M., Nawaz, M. and Iqbal, N., 2012. Comparative seed storage protein profiling of mung bean genotypes. Pak. J. Bot., 44: 1993-1999.

Hamidian, M., Hawkey, J., Holt, K.E. and Hall, R.M., 2015. Genome sequence of Acinetobacter baumannii strain $\mathrm{D} 36$, an antibiotic-resistant isolate from lineage 2 of global clone 1. Genome Announc., 3(6): Article ID e01478-15. https:// dx.doi.org/10.1128\%2FgenomeA.01478-15

Kaga, A. and Ishimoto, M., 1998. Analysis of expressing genes around bruchid resistance gene, Resubmitted (DEC-1998) to the EMBL/ GenBank/DDBJ databases (www.uniprot. org/).

Khan, M.A., Asaf, S., Khan, A.L., Jan, R., Kang, S.-M. and Kim, K.-M., 2020. Thermotolerance 
effect of plant growth-promoting Bacillus cereus SA1 on soybean during heat stress. $B M C$ Microbiology, 20: Article ID 175. https://doi. org/10.1186/s12866-020-01822-7

Lowry, D.H., Rosengrough, N.J., Farrand, A.L. and Randall, R.J., 1951. Protein measurement with phenol reagent. J. Biol. Chem., 193: 265-275.

Mansoor, S. and Naqvi, F.N., 2013. Effect of heat stress on lipid peroxidation and antioxidant enzymes in mung bean (Vigna radiata $L$ ) seedlings. Afr. J. Biotech., 12(21): 3196-3203. https://doi.org/10.5897/AJB12.2808

Mendoza, E.M.T., Adachi, M., Bernardo, A.E.N. and Utsumi, S., 2001. Mungbean [Vigna radiata (L.) Wilczek] globulins: purification and characterization. J. Agric. Food Chem., 49(3): 1552-1558. https://doi.org/10.1021/jf001041h

Miclaus, M., Xu, J.H. and Messing, J., 2011. Differential gene expression and epiregulation of alpha zein gene copies in maize haplotypes. PLoS Genet, 7(6): e1002131. https://doi. org/10.1371/journal.pgen.1002131

Mizutani, M., Ward, E., Dimaio, J., Ohta, D., Ryalsand, J. and Sato, R., 1993. Molecular cloning and sequencing of a cDNA encoding mung bean cytochrome P450 (P450C4H) possessing cinnamate 4-hydroxylase activity. Biochem. Biophy. Res. Commun., 190(3): 875880. https://doi.org/10.1006/bbrc.1993.1130

Nnadi, N.E., Vos, R., Hasami, M.H., Devisetty, U.K. and Aguiy, J.C., 2018. Draft genome of Mucuna pruriens seed. Pharmacy, African Centre of Excellence in Phytomedicine Research, University of Jos, Jos 234, Nigeria. (From NCBI Database: www.ncbi.nlm.nih. gov/protein)

Salanoubat, M., Lemcke, K., Rieger, M., Ansorge, W., Unseld, M., et al. 2000. Sequence and analysis of chromosome 3 of the plant Arabidopsis thaliana. Nature, 408(6814): 820-
823. https://doi.org/10.1038/35048706

Sato, S., Kaneko, T., Kotani, H., Nakamura, Y., Asamizu, E. and Miyaj N., 1998. Structural analysis of Arabidopsis thaliana chromosome 5. IV. Sequence features of the regions of $1,456,315$ bp covered by nineteen physically assigned $\mathrm{P} 1$ and TAC clones. DNA Res., 5(1): 41-54. https://doi.org/10.1093/dnares/5.1.41

Siddiqui, M.H.,Alamri, S.A.,Al-Khaishay, M.Y.Y., Al-Qutami, M.A., Ali, H.M. and Khan, N.M., 2017. Sodium nitroprusside and indole acetic acid improve the tolerance of tomato plants to heat stress by protecting against DNA damage. J. Plant Interact., 12(1): 177-186. https://doi.or g/10.1080/17429145.2017.1310941

Steel, R.G.D. and Torrie, J.H., 1997. Principles and procedures of statistics: A biometrical approach: $3^{\text {rd }}$ edn. Singapore: McGraw Hill Book Co. https://trove.nla.gov.au/version/26560275

Tabata, S., Kaneko, T., Nakamura, Y., Kotani, H., Kato, T., et al., 2000. Sequence and analysis of chromosome 5 of the plant Arabidopsis thaliana. Nature, 408(6814): 823-826. https://doi. org/10.1038/35048507

Vasconcelos, I.M., Morais, J.K.S., Siebra, E.A., Carlini, C.R., Sousa, D.O.B., Beltramini, L.M., Melo, V.M.M. and Oliveira, J.T.A., 2008. SBTX, a new toxic protein distinct from soya toxin and other toxic soybean [Glycine max] proteins, and its inhibitory effect on Cercospora sojina growth. Toxicon., 51(6): 952-963. https:// doi.org/10.1016/j.toxicon.2007.10.005

Wang, G., Zhou, S., Luo, Y., Ma, C., Gong, Y., Zhou, Y., Shuangshuang, G., Huang, Z., Lianlian, Y., Yue, H. and Bian, Y., 2018. The heat shock protein $40 \mathrm{LeDnaJ}$ regulates stress resistance and indole-3- acetic acid biosynthesis in Lentinula edodes. Fungal Genet. Biol., 118: 3744. https://doi.org/10.1016/j.fgb.2018.07.002 